\title{
Economic Injustice as an Understanding of the Existence of Two Americas-Wealth and Poverty
}

\author{
Fred Bedell \\ Del G Publishing, Fountain Hills, AZ, USA \\ Email: BedellD@aol.com
}

Received 28 April 2014; revised 29 May 2014; accepted 19 June 2014

Copyright (C) 2014 by author and Scientific Research Publishing Inc. This work is licensed under the Creative Commons Attribution International License (CC BY). http://creativecommons.org/licenses/by/4.0/ (c) (7) Open Access

\begin{abstract}
This essay speaks to government policies, the practices of the corporate sector, the inherited wealth of the few, and the consumptive behavior of the masses as the underlying causes of economic injustice. This is perceived as leading the country to an oligarchy.
\end{abstract}

\section{Keywords}

Economic Injustice, Economic Crisis, Capitalism, Academic Gap, Education, Financial, Poverty, Consumerism, Wealth, Affluent, Less Affluent

\section{Introduction}

This paper is written in the context of unifying the themes of previous papers written by the author: "Historical Illiteracy as an Understanding of Income Inequality” (Bedell, 2013a) and “The Causes and Flaws in our Economic System" (Bedell, 2013b), as well as the accumulation of inherited wealth that is leading the society to an oligarchy. We hope to enlighten the reader as to the causes that have led to the economic malaise of the two Americas - the affluent and the less affluent.

In this essay, we will point out that the causes of this situation are not only the questionable policies of the government, the practices of the corporate sector, and the inherited wealth of the few, but also of our own doing that usually is not found in public discourse.

In a recent telecast of the Bill Moyer's Journal's TV Program, aired in April of 2013, Mr. Moyer's guests, Taylor Branch (historian) and James Cone (theologian), discussed Dr. Martin Luther King's crusade for economic freedom. Subsequently during this period, King's proposed doctrine for economic justice was formulated.

This movement took place in the 1960s, which begs the question as to whether or not we are further along to- 
day—obviously not. What happened? We will present facts and insights that will shed some light on this dilemma.

\section{Economic Injustice}

Dr. Martin Luther King's speech delivered at Stanford University on April 14, 1967, focused on the emergence of the two Americas in our society-one for the affluent and the other for the impoverished. Before he gave that speech, he spoke to an audience at the Riverside Church in New York City on April 4, 1967, concerning a revolution of values, which essentially called for a shift from a culture of materialism to one of humanity. King changed his mission at that point in time from a focus on civil rights to the fight against poverty and for economic justice (Martin Luther King's Speeches).

He proposed the following areas to be included in an economic and social Bill of Rights:

- The right of every employable citizen to a decent job;

- The right of every citizen to a minimum income;

- The right to a decent house and the free choice of neighborhood;

- The right to an adequate education;

- The right to participate in the decision-making process;

- The right to the full benefits of modern science in health care.

To say the least, we are a long way from achieving King's aspirations. The gap between the affluent and the less affluent has increased exponentially since his time, whereas today $1 \%$ of the population controls $40 \%$ of the country's wealth.

Adding to this analysis, Author Timothy Noah recently stated in an article published in the May 19, 2013, Sunday edition of the New York Times, titled "The 1 Percent are Only Half the Problem", that the rise of the educated class creates a significant income gap between this class and the less educated class (high school or less). Years ago, the income gap between these two groups was less stark because of the influence of labor unions, which gave rise to the middle class. The stagnation of the wage scale today for the middle class can be attributed to the decline of the unionization movement (Noah, 2013).

The decline of labor unions in this century is exemplified by the situations (to name a few) in Michigan which has become a "right to work state" and the defeat of unionization in Wisconsin. The Labor Department recently reported that during President Obama's first term, the percentage of workers belonging to unions declined faster than it did during George W. Bush's two terms. The unionization rate is 11.2 percent of all workers. Private sector unionization fell from 6.9 percent to 6.6 percent and the government unionization rate dropped from 37 percent to 35.9 percent (Wikipedia).

No doubt, this decline can be attributable to today's economic and political climate.

\section{Beginnings}

The constitution begins with "We the People" which purports to assert the supremacy of the commoner over and against the claims and inherent power of kings and government. "The constitution was for all intents and purposes designed to further the acquisition of property for the privileged class", as stated by Khalil Muhammad in his book entitled "The Condemnation of Blackness". Evidently, words did not match the reality that all men are created equal, as non-privileged class people (dark skinned, women and children) were not included. How does wealth develop for the privileged few? Prior to the establishment of America, the world's elite and powerful got its labor from the peasants and the underprivileged. During the development of this country, wealth was acquired through the exploitation of labor from indentured servants and slaves (Muhammad, 2010).

\section{Educational Opportunity}

The fortune of birth, unfortunately, is a determinant factor in economic justice. It is even more evident in the realm of education. In a recent article published in the April 28, 2013, Sunday edition of the New York Times, written by Sean F. Reardon entitled "No Rich Child Left Behind", the author states a fact. "... the rich perform better in school on average than children from middle class or poor families". Consequently, they have better grades, score better on standardized tests, and have higher graduation rates and higher rates of college enrollment completion. His premise is that money is a better predictor of success than race (Reardon, 2013). 
Mr. Reardon states that over the last few decades, differences in educational success between high income and lower income students have grown substantially. He also implies that the focus of education this year is the question "Can education provide a path for students out of poverty?" Whatever has been going on in schools has not reduced educational inequality between these two groups (higher income vs. lower income). In effect, the author suggests that the academic gap is widening, because rich students enter kindergarten better prepared for school success than middle class students do—no surprise here.

A June 17, 2013, article in the Arizona Republic newspaper cites that the debate for affirmative action has shifted to class. In the last decade (circa 1990s) the US Supreme Court focused on race as a barrier to college enrollment which today is no longer the case. The debate has shifted to socio-economic disadvantaged students regardless of race.

Most recently, The Supreme Court (4/21/14) banned public colleges from using race as a factor in college admissions (6 - 2 vote). The decision was not purportedly about the constitutionality of race-conscious admissions but about the merits.

Class-based affirmative action is based on economic circumstances-giving poor students a boost regardless of skin color. This policy is often regarded as a replacement for race-based affirmative action in college admissions (PBS News Hour, 2014).

"The Cultural Zeitgeist has changed", said Peter Sachs, author of the book "Tearing Down the Gates: Confronting the Class Divide in Education" (Sachs, 2009). Recent polling data in this area indicates that barriers to low income students are a serious problem that should be addressed; many minority students are also low income.

It is evident that quality higher education is moving in the direction of the wealthy. A report by The Lumina Foundation states that "The large and persistent achievement gaps between races in the US is increasing as attested by the following:

- 60 percent of Asian adults have a college degree;

- 43 percent of white adults have a college degree;

- 27 percent of black adults have a college degree;

- 19 percent of Hispanic adults have a college degree”.

The study further indicates that whites and Asians are doing better than their parents, as compared to blacks, Hispanics and Native Americans who are doing worse. So much for American exceptionalism.

Money helps families provide cognitively stimulating experiences for their young children. Consequently, a stable environment is provided that is conducive to parents reading to their children and providing access to quality childcare and preschool opportunities.

High-income families are focusing on successful practices in school—cognitive development and successful educational activities.

We as a country should be investing more resources in preschool programs instead of cutting programs in this area as the present Congress is proposing. Budget cuts in this area are decimating these programs, and we wonder why poor kids cannot get ahead — two Americas—rich and poor.

\section{Corporate Behavior}

Ever wonder what the Federal Reserve System is? Most people think it is a government agency. It is not. The Federal Reserve is the central banking system of the United States created by the enactment of the Federal Reserve Act (December 1913) in response to a series of financial panics. It is comprised of a presidentially appointed board of directors, confirmed by the Senate, which is responsible for setting monetary policy. It controls the supply of money by targeting interest rates for the purposes of promoting economic growth and stability. Monetary policy differs from fiscal policy, which refers to taxation, government spending and associated borrowing (Wikipedia).

The Federal Reserve started with a group of powerful bankers who engineered a phony crisis in the early 1900s to convince the American people that the country needed a strong central bank to help regulate the economy and bring Wall Street to heal to their wishes.

The bankers used a theory referred to as "The Hegelian Dialectic" which is where a group (bankers in this case) creates a problem knowing full well in advance how people are going to react to it. They then began agitating for something to be done about the problem. Once the populace is worked up enough and wants some- 
thing to be done, the parties behind the problem (bankers in this case) unveil the solution. The people are happy to have a solution and demand that it happens. They never realize that they have been manipulated (blue pill). This scenario led to the creation of the Federal Reserve ("Secrets of the Federal Reserve" by Eustace Mullins). (Mullins, 2008).

Corporations, in their mission to amass wealth, indulge in policies and practices at the expense of the many for the gains of the few (shareholders). Dave Bollier (Link Television, 2012) depicts the struggle between the marketplace and the commons, which is defined as all the things we as a society collectively own, e.g., air and water, and is being systematically enclosed by the free market through privatization for the sake of profit.

Recently, Susan Crawford, a professor of law at the Benjamin Cardoza School of Law in New York City, spoke to the monopoly of the telecom industry by four corporate organizations (Bill Moyers and Company Telecast, 2013). Her major point regarding Internet access for the public is that we are paying more and getting less than other developed countries for a similar service. This practice in her opinion leads to income inequality as these corporations raise prices and stifle competition by dividing markets for their economic gain. This activity denies equal opportunity to people who cannot pay fees for Internet services that provide education, job opportunities and information about political activities needed for life enhancement. The author characterized this situation as a "digital divide"- two Americas (Crawford, 2013).

Further examining corporate behavior, corporations have used the legislative and judicial process to advance their fiscal agenda as evidenced by the passage of the "Citizens United Act" (Citizens United Act, 2012) which permitted corporations to contribute money to federal officials and candidates. In addition, corporations formed a nationwide consortium termed ALEC (American Legislative Exchange Council). This organization works side by side with elected state officials with the aim of developing laws for their self-interests, e.g., "Stand Your Ground Law" sponsored by the National Rifle Association and adopted by several states. This law brought attention to the public in the shooting death of Trevor Martin in the state of Florida.

\section{Capitalism}

Capitalism as an economic system has come into question as a flawed system over the last 30 years. It is defined as an economic and political system in which a country's trade and industry is controlled by private owners for profit rather than the government.

Professor Ha-Joon Chang in his book entitled “23 Things They Don’t Tell You about Capitalism”, excerpted in an article in the Information Clearing publication on 3/24/13, speaks about the ills of capitalism. He states "The aspects of capitalism's strengths center upon the interests of the shareholders". Some are listed as follows:

- "Capitalism is best, because it rewards those who are most productive.

- Capitalism is best, as it is capable of producing what is needed.

- Individuals are inherently self-seeking and do not cooperate, so the market is needed to ensure the highest wellbeing for society".

Chang debunks these myths by offering the following observations:

- "Ever-increasing economic growth/rationale for capitalism long since ceased to bring increasing marginal returns to wellbeing.

- All the extra growth and wealth accumulated since the 1970s could be distributed more fairly.

- The combined wealth of the world's 500 wealthiest people is equal to that of $60 \%$ of the world's population. The top $1 \%$ in the US has more wealth than the entire bottom $90 \%$ ".

So Professor Chang postulates that the key rationale and driver of capitalism—-the treadmills of accumulation-makes no sense anymore. He states, "Inequality and poverty, consumerism, debtonation, polluted values, the roller coaster of booms and busts and the creation of flawed financial instruments are the ills of capitalism" (Chang, 2013).

In 2010, the US experienced an economic meltdown. Professor Richard Wolff, an economics professor at the University of Massachusetts gave his view of how capitalism hit the fan on a Link TV Program (12/11). He stated that, "One hundred and fifty years of wage increases allowed the population to consume more, however, in the 1970s real wages stopped rising and haven't risen since". Professor Wolff offers the following observations as to why it stopped:

1) "Technology — the advent of the computer reduced the work force.

2) Competition from other countries came into play (1945-1970) as the US was then the dominant power as a 
consequence of WWII.

3) War torn countries became competitors to the US and then they out produced us.

4) The US concluded, "If you can't beat them, join them”. They exported jobs. In addition, the use of the computer, reducing the need for jobs during the same time jobs were being moved out of the country, caused the bargaining power of the worker (unions) to diminish (Wolff, 2011).

Women during this period entered the work force. This fact, coupled with the influx of immigrants entering the country, made for fewer jobs, and with the use of technology and exported jobs, this resulted in a significant negative impact on the economy and job creation.

These observations as stated suggest that capitalism, as an effective driver of the economy, is questionable. Let's look at inherited wealth.

\section{Inherited Wealth}

French Economist Thomas Piketty’s recent book, “Capitalism in the Twenty-First Century”, was discussed on the Bill Moyer's TV Program (4/18/14) with guest Paul Krugman (Bill Moyers and Company Telecast, 2014a). The crux of the discussion centered on the view that the road a society is moving toward is characterized as an oligarchy (inherited wealth). In effect, the rate of return on capital exceeds the rate of growth of output and income (economic growth), as capital is concentrated in fewer and fewer hands. This is giving the rich power over politics, government and society (patrimonial capitalism).

Between 1977 and 2009, 60\% of the national income went to the richest 1\% of Americans. Piketty's main point here is that the rate of return on capital $(4 \%-5 \%)$ compared to the rate of the growth of the economy is much slower (2\% - 3\%) (Piketty, 2014). What this means is that if you have a large fortune you can live well and are in the position to put a large portion of that income aside which will grow faster than the economy (Bill Moyers and Company Telecast, 2014a).

On April 15, 2014 (tax day), the AFL/CIO reported last year that the CEOs of 350 top American companies were paid 331 times more than the average worker. CEOs made an average of \$11.7 million dollars compared to the average worker’s earnings of \$35,239 dollars (Moyer).

Many millionaires pay a lower federal tax rate than many middle-class families in America (Robert ReichSalon). The IRS allows carried interest-a lower tax rate. State and local governments tax the poorest Americans to pay an average tax rate of $20 \%$, whereas the wealthier pay an average tax rate of $11 \%$, and the richest $1 \%$ in the country pay half that amount-5.6\% (Moyer).

Elizabeth Warren, a recently elected United States Senator, has written a book entitled “A Fighting Chance” that chronicles her life, depicting how her parents sacrificed and worked to enable her and her siblings to succeed. She states that they were lucky enough to grow up in an America that invested in kids like her family to build a future where they could flourish. She states, “Here's the hard truth: America isn’t building that kind of future any longer. Today the game is rigged-rigged to work for those who have money and power. Big corporations hire armies of lobbyists to get billion dollar loopholes into the tax system and persuade their friends in Congress to support laws that keep the playing field tilted in their favor” (Warren, 2014).

\section{Implications for Working People}

The major political implication is that the wealthy can buy the political system that serves their interests; consequently, inequality is transferred across generations. Observe the political machinations over voter registration in most states. The US has much more unequal distribution of income than other advanced countries, usually coming from government action. For example, European counties have higher taxes overall that are used to pay for programs of aid such as health care, income support for people with low incomes and the distribution of wealth accounts for this action-controversial policy in some quarters of the country (Krugman, 2014).

Krugman suggests that the average American is richer that the average Frenchman, but government policies provide a higher standard of living. He also feels that redistribution of income has been characterized as unAmerican; consequently, the political system has railed against it. Underlying this view is race, as race is framed (structure of ideas) to garner votes by politicians.

Barry Lopez, author of "Dog Whistle Politics" (a metaphor for coded talk on race) discussed his book on the Bill Moyers and Company Telecast (circa 2014b). The context of the discussion was how coded politics is a means to use coded appeals that carefully manipulate hostility toward non-whites. Examples are criminals, wel- 
fare cheats, illegal aliens and Sharia law in the heartland. In the recent past, dog whistle politics has driven a large majority of white voters to adopt a self-defeating hostility toward government and subsequently has remade the nature of race and racism (Lopez, 2013).

Lopez explains how politicians use dog whistle politics, often backed by concentrated wealth, to manipulate racial appeals to win elections and support regressive policies that help corporations and the super-rich, in the process wrecking the middle class.

Over the last half century, conservatives have used racist pandering to win support from white voters for policies that principally favor the wealthy. The tragedy of this strategy is that how race is used to convince many white voters to vote against their own apparent interests.

\section{Economic Crisis}

In 2007 the real estate market crashed. Why? Some look at the theory of "Efficient Market Hypothesis" which states that as the price of goods rise, the tendency is to demand less of it (supply and demand). If the price of a good goes up, we tend to hold on to it, e.g., a refrigerator. Conversely, if the good is treated like an asset as people treat houses by continually refinancing, it depletes the equity in that asset. This activity resulted in mortgages exceeding the value of the house, often resulting in foreclosures and bankruptcy for some homeowners.

Greed became the predominant motive behind the financial transactions that led to this crisis as banks engaged in a practice termed as "Predatory Lending"-giving loans to people who could not repay them, resulting in foreclosures. These mortgages were packaged with other financial instruments in a financial portfolio termed a CDO (Collaterized Debt Obligation), and sold to investors. When these instruments failed, the market crashed and the investors bailed out, causing the crisis.

Bankers maximized their profits through charging high transaction fees upfront, which boosted their profits at the expense of the poorest Americans who espoused to attain the American dream through the accumulation of debt.

\section{Consumerism}

Consumerism is defined as a theory that a country that consumes goods and services in large quantities will be better off economically. Boston University Professor Andrew Bacevich’s book entitled "The Limits of Power" suggests that one of the factors in the economic crisis is of our own making. We are a consumptive society as we have been afforded the luxury of having cheap goods, easy credit and cheap oil (energy). This mindset was enhanced by the masters of Madison Avenue who indoctrinated the public with the buying credo based on "Wants and Not Needs" (Bacevich, 2008).

Moreover, the current generation exacerbates this dilemma by their need for instant gratification for goods and services by purchasing items through debt as compared to their parent's generation whose buying practices were based on saving money and then purchasing the items.

Thomas Friedman, in his column in the Sunday edition of the New York Times (3/12), characterized this mindset slightly differently by suggesting that, "We are a Diet Coke culture, as we want the sweetness without the calories; the consumption without the savings and the safety net without the taxes" (Friedman, 2012).

Fareed Zaharia's book entitled "The Post American World" points out that the rise of the economies of developed countries is in direct competition for resources with the US, which has had a major impact on our economy and job creation. This situation is hard for us to accept (Zaharia, 2008).

\section{Great Deception}

Jim Macgregor, a retired doctor, former family practitioner and visiting medical officer for the prisons in Scotland, wrote an article In the Information Clearing House Publication (3/13), entitled "Neo Fascism in America". (Macgregor, 2013) Dr. Macgregor intimates that his comprehension of American politics was influenced by the essay "Escaping the Matrix", written by Richard K. Moore (Moore, 2005), which coincidently led to the making of the film "The Matrix", produced by the Wachowski Brothers. The major theme of the film is truth vs. illusion, which is exemplified when the main character is confronted with choosing a red pill (truth and reality) and a blue pill (untruth and illusion). The blue pills are illusions created by the wealthy elite. He states that the matrix is the world that was pulled down over our eyes to hide the truth; as long as the matrix exists, humanity cannot 
be free. Television and radio stations are owned by the ruling elite who control the content of information provided (The Matrix).

Environmentalist Robert Kennedy, III, in an interview on the Tavis Smiley Telecast in June of 2011 (Telecast, 2011), referred to the use of the legislative and judicial process (we see this in Citizen's United Act passed by the Supreme Court) to enhance corporate power. A specific example is the repealing of the Fairness Doctrine for Media.

Teddy Roosevelt, then president, characterized corporations as "malefactors of great wealth" and enacted the Sherman Anti-Trust Act that broke up monopolies. In addition, the Act instituted the Public Information Act (Fairness Doctrine) that stated that the airways belonged to the public, and broadcasts were to be used to inform the public. (Bollier's statement on enclosing the commons is relevant here). In 1980, President Ronald Reagan repealed the "Fairness Doctrine" which was viewed by some as a reward for the Christian right who helped his election. Today, five corporations control the majority of media outlets. In the last 15 years, most of the investigative reporters in this medium were fired and most of the foreign news bureaus eliminated. News organizations are dependent on corporate money for their revenue, which often influences what type of news content is aired (Kennedy, 2011).

\section{Some Thoughts}

After writing the two papers as referenced above- "Historical Illiteracy as an Understanding of Income Inequality" and "Flaws and Causes of the Economic Crisis of 2007", I searched for a unifying theme to coordinate the two papers. Economic injustice seems to have been what I was looking for.

On the Charles Rose television show (10/24/12), Zbigniew Brzezinski, the former national security adviser to President Jimmy Carter, participated in a discussion with other guests regarding the topic of American foreign policy following a series of Presidential debates, and he offered the following observations regarding the American public:

1) "The American public does not understand the world.

2) The American public does not understand the world and is not informed about it.

3) The American public entertains a great many misconceptions and prejudices about the world and is susceptible to demagoguery which often propagates fear and makes it difficult to have a coherent and sustainable foreign policy" (Brzezinski, 2012).

Conversely, an observation was given on this subject in an Alternet article, which stated that Americans are generally only interested in issues that affect them personally. I suggest that this contributes to Americans being misinformed and uninformed which often results in their voting against their self-interests.

"The blue pill is dispensed in the form of matrix propaganda, deliberately formulated to conceal the truth", stated Dr. Macgregor, and he lists 14 defining characteristics that are common to fascist states. For the purpose of emphasis as to the theme of this paper, we will depict only three.

1) "Identification of enemies/scapegoats as a unifying cause: People are rallied into a unifying patriotic frenzy over the need to eliminate a perceived threat or foe, e.g., racial, ethnic, religious, minorities, liberals, communists, socials, and terrorists. (Dog whistle politics is evident here).

2) Corporate power is protected: The industrial and business aristocracy of a non-democratic nation is often the one who puts the government leaders into power, creating a mutual business/government relationship and power elite.

3) Labor power is suppressed, because the organizing power of labor is the only real threat to a non-democratic government. Labor unions are either eliminated or suppressed" (Macgregor, 2013).

\section{Observations}

My overall thought after extensive research for this effort led me to look at two emotions-greed for the wealthy and power elite and fear for the impoverished and powerless. When we are misinformed/uninformed and we cannot or will not stand up to the injustice of our historical past, then injustice becomes an ever-present constant in our daily lives.

The facts speak for themselves as we are headed for an oligarchy. Economic injustice became such a major issue that a movement was formed to address these concerns-Occupy Wall Street-which unfortunately founded and left the majority of the country with a dilemma. 
Fear for our livelihoods and even the thought of life and death consequences prevent us from taking action against the aggressive positions of the establishment. History shows us the consequences of people taking such actions, either through discrediting people or assignation, e.g., Kennedys, King, Malcolm X to name a few. The question is, "Where do we go from here?"

\section{Conclusion}

The facts speak for themselves. Corporations and wealthy people manipulate the economic system through corporate policies and practices, as well as the use of hiring lobbyists, to influence legislation to advance their agendas. This often does not work for the benefit of the masses.

In researching and writing articles, the writer searches for facts to reaffirm his or her beliefs. We take parts of records and documents and develop an argument to defend our position. It is within this context that this essay is written.

I always want to enlighten and provoke thought for my readers.

\section{References}

Bacevich, A. (2008). The Limits of Power. New York, NY: Henry Holt and Company, LLC.

Bedell, F. (2013a). Historical Illiteracy as an Understanding of Income Inequality. Fountain Hills, AZ: Del G Publishing.

Bedell, F. (2013b). Flaws and Causes of the Economic Crisis. Fountain Hills, AZ: Del G Publishing.

Bill Moyers and Company (2013). TV Program. Susan Crawford. Captive Audience, 2/8/13.

Bill Moyers and Company (2014a). TV Program. Paul Krugman Interview. Charles Piketty’s Book, Capitalism in the 21st Century, 4/21/14.

Bill Moyers and Company (2014b). TV Program. Taylor Branch \& James Cone Interview on Economic Freedom (4/14).

Bollier, D. (2012). This Land is Our Land. Link TV Program.

Brzezinski, Z. (2012). Interview on the Charlie Rose TV Program, 10/24/12.

Chang, H. (2013). 23 Things They Don't Tell You About Capitalism. Clearing House Publication, 3/24/13.

Citizens United Act (2012). The 1 Percent Court. http://www.thenation.com/article/169884/1-percent-court

Crawford, S. (2013). Digital Divide-Two Americas

Friedman, T. (2012). New York Times (3/12).

Lopez, I. H. (2013). Dog Whistle Politics. New York, NY: Oxford University Press.

Macgregor, J. (2013). Neo-Fascism in America. Information Clearing House (3/13).

http://www.informationclearinghouse.info/article7553.htm

Martin Luther King’s Speeches. Stanford University (4/14/64) and Riverside Church (4/13).

Moore, R. (2005). Escaping the Matrix. Redwood City, CA: The Cyberjournal Project.

Muhammad, K. (2010). The Condemnation of Blackness. Cambridge, MA: Harvard University Press.

Mullins, E. (2008). Secrets of the Federal Reserve.

Noah, T. (2013). The 1 Percent Are Only Half the Problem. New York Times (5/19/13).

PBS News Hour (2014). Supreme Court Decision on Affirmative Action (4/22/14).

Piketty, T. (2014). Capitalism in the 21st Century. Belknap Press.

Reardon, S. (2013). No Rich Child Left Behind. New York Times, 4/28/13.

Sachs, P. (2009). Tearing Down the Gates: Confronting the Class Divide in Education. Berkley and Los Angeles, California: University of California Press.

Smiley, T. (2011). TV Program. Guest, Robert Kennedy, III (6/11). https://www.youtube.com/watch?v=mEMhzN3tqYY

Warren, E. (2014). A Fighting Chance. New York, NY: Henry Holt and Company, LLC.

Wikipedia (as Referred to in the Text).

Wolff, R. (2011). Capitalism Hits the Fan. Link TV (12/11).

Zaharia, F. (2008). The Post American World. New York, NY: W. W. Norton \& Company. 
Scientific Research Publishing (SCIRP) is one of the largest Open Access journal publishers. It is currently publishing more than 200 open access, online, peer-reviewed journals covering a wide range of academic disciplines. SCIRP serves the worldwide academic communities and contributes to the progress and application of science with its publication.

Other selected journals from SCIRP are listed as below. Submit your manuscript to us via either submit@scirp.org or Online Submission Portal.
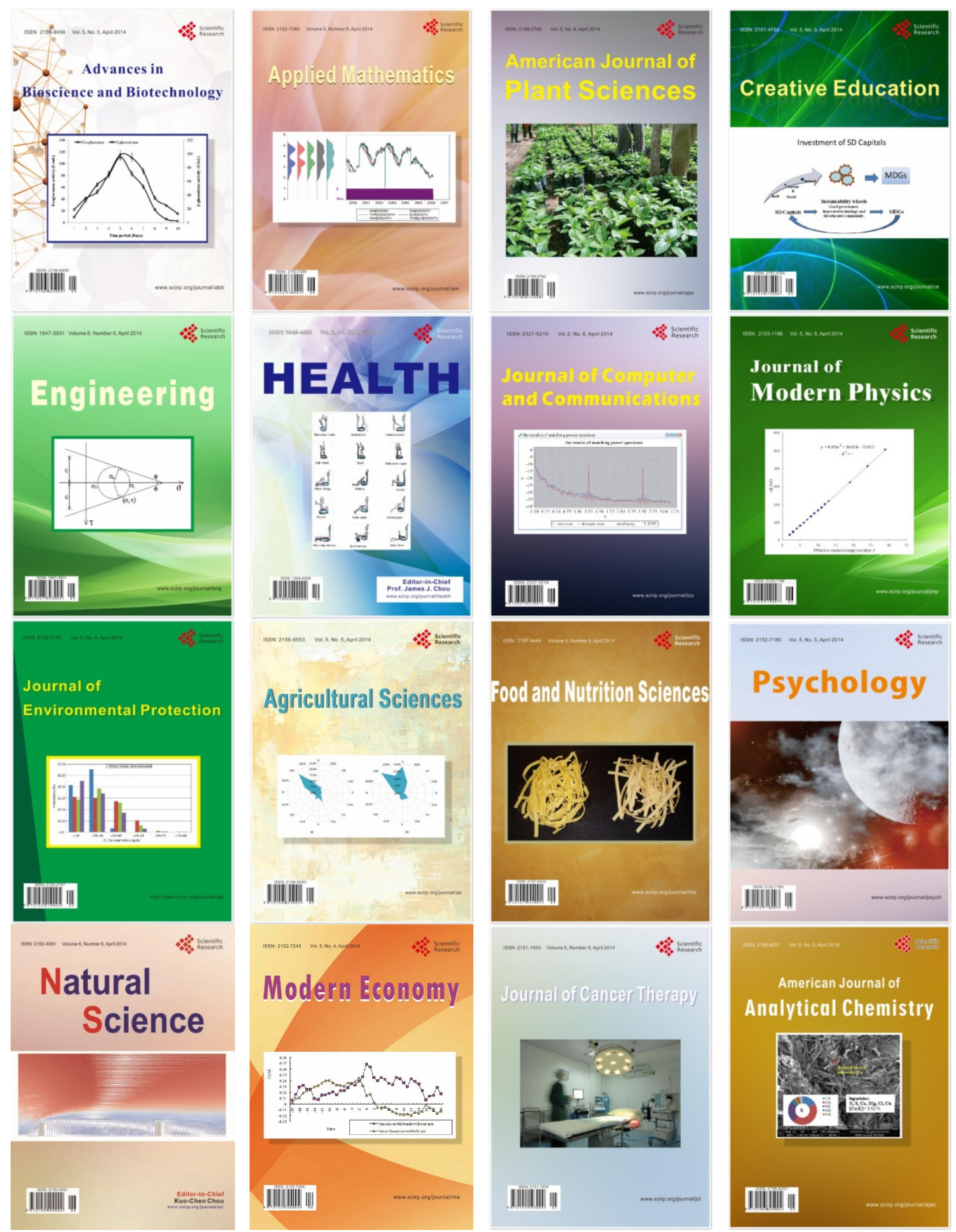